\title{
Fungal Malignant Otitis Externa with Facial Nerve Palsy: Rare Case
}

\author{
Said Anajar*, Tatari Moutaa Mohammed, Redallah Abada, Mohammed Roubal and Mohammed Mahtar \\ Service ORL et chirurgie cervico-faciale - Hôpital 20 Août, Maroc
}

Submission: April 17, 2017; Published: May 15, 2017

*Corresponding author: Said Anajar, Service ORL et chirurgie cervico-faciale - Hôpital 20 Août, BD bordeaux rue ait baha N 5 Casablanca Maroc, Tel: 212660782808; Email: Anajar.said.med@gmail.com

\begin{abstract}
Malignant external otitis manifests as a painful inflammation of the external ear canal, associated with purulent otorrhea and granulation a polyp, MEO is a rare infection of the temporal bone primarily affecting elderly patients and diabetics or immunocompromised individuals. We present a rare case of Fungal malignant otitis externa with facial nerve palsy where formal tissue sampling revealed the diagnosis and the patient was successfully treated with voriconazole

Keywords: Fungal; Malignant; External otitis; Biopsy
\end{abstract}

\section{Introduction}

Malignant external otitis (MEO) manifests as a painful inflammation of the external ear canal, associated with purulent otorrhea and granulation polyps, MEO is a rare infection of the temporal bone primarily affecting elderly patients and diabetics or immunocompromised individuals, which may have dismal prognosis if treatment is not prompt and adequate. Pseudomonas aeruginosa is responsible for almost all cases, although a few cases may be due to other microorganisms [1-3], Aspergillus species and Candida albicans. There are few cases reported of fungal MOE. We present a case of fungal malignant otitis externa complicated by a facial nerve palsy that proved very difficult to achieve a formal diagnosis

\section{Case}

In 2015, a 65-year-old insulin-dependent male with diabetes presented to our hospital complaining of otalgia and otorrhoea lasting for 2 weeks. On examination, the right ear canal was full of purulent secretion, oedematous and occupied by extensive granulation tissue, the tympanic membrane was hyperaemic and thickened. Ear discharge was cultured for bacteria and mycosis with isolation of $P$. aeruginosa, CT imaging demonstrated a left skull base osteomyelitis (Figure 1). Treated over a period of three weeks with oral and topical ciprofloxacin and control of diabetes, but when still on treatment, he developed right facial nerve palsy grade $\mathrm{V}$ (House-Brackmann) (Figure 2).
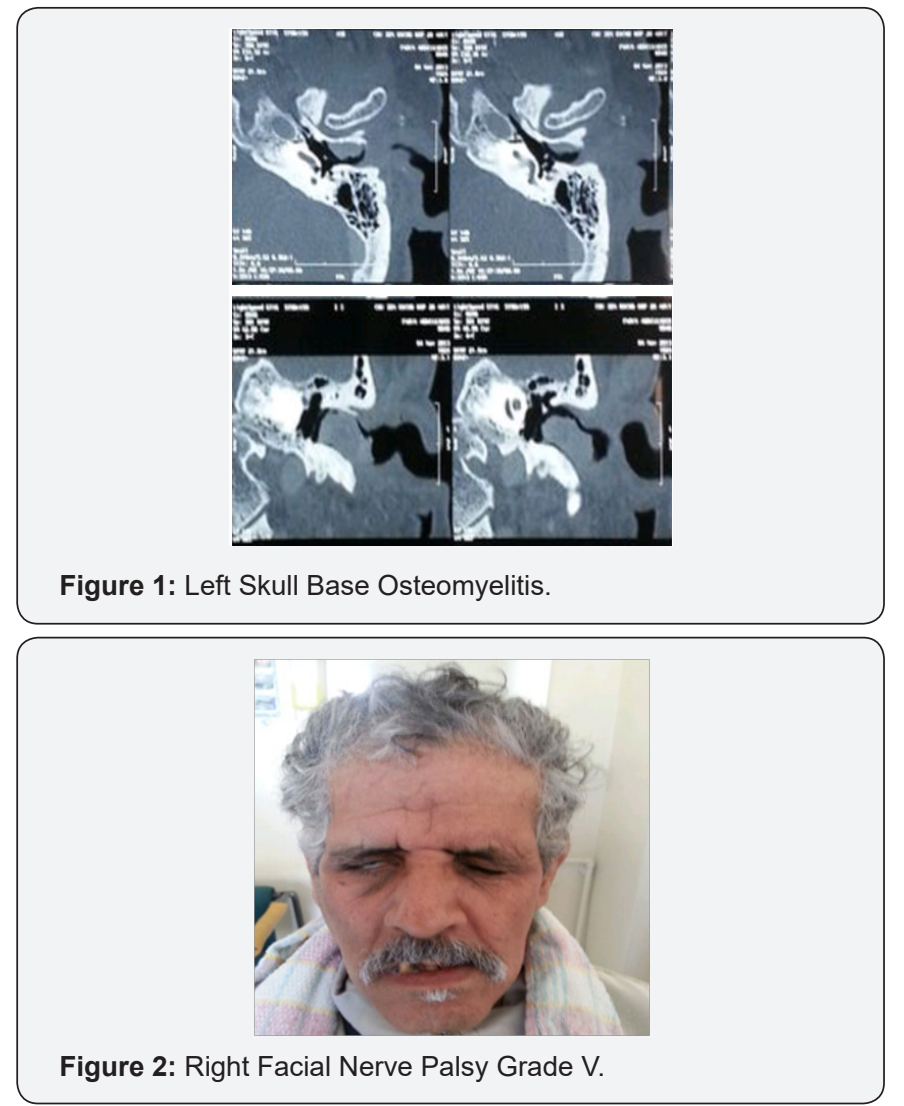
The right ear canal was full of purulent secretion, oedematous and occupied by extensive granulation tissue, CT and MR imaging demonstrated a left skull base osteomyelitis with involvement of the temporal bone and extension to the clivus and facial and neck tissue Tissue biopsies were taken directly from granulation tissue and, in contrast to the previous microbiology, Aspergillus flavus was isolated. Treatment was commenced with intravenous voriconazole for 1 month, followed by subsequent conversion to oral voriconazole. The previous treatment with ciprofloxacin was continued, within a month of commencing antifungal therapy, we realize a meatoplasty with mastoidotympanoplasty to remove the infected and necrotic tissue, after 2 month of traitement facial palsy resolved completely and he was discharged from clinic pain-free with an otoscopically normal canal. Oral voriconazole therapy was continued for 12 months after resolution of symptoms.

\section{Discussion}

Cranial nerve palsies are frequently seen in fungal MOE [4]. However, many reported cases have not demonstrated a significant improvement following treatment, possibly due to the delayed isolation of the pathogen and initiation of antifungal treatment. Halsey et al. [4] reported the presence of facial nerve palsy in $75 \%$ of patients with Aspergillus infection, compared with only $34 \%$ in MOE due to Pseudomonas, the infection spreads through the fissures of Santorini, small perforations in the cartilaginous floor of the external auditory canal, and then medially until it reaches the skull base [5]. Here, it causes bony destruction, the facial nerve being most commonly affected due to the proximity of the stylomastoid foramen to the ear canal. The presence of facial nerve palsy has been suggested to represent a poor prognosis in patients with MOE along with coexisting immunosuppression [6].

Fungal infections are generally more invasive than bacterial disease, all the other clinical and radiological features, including survival, are similar $[2,3,7]$. Thus, even the isolation of Pseudomonas from aural discharge may be not sufficient or specific enough to distinguish between the two forms, Aspergillus is also frequently isolated from external auditory canal smears and diagnosis of fungal MEO should be based on histopathologic confirmation on deep tissue biopsy or isolation from blood cultures or fistula exudates [8]. No diagnostic conclusions can be drawn from single positive cultures from the external auditory canal or from middle ears with chronic perforations [8].
The Aspergillus identified in our patient was isolated on deep tissue specimens, Voriconazole is currently recommended as first line treatment in cases of invasive aspergillosis [9], and its use is increasing since its launch in 2002. The intravenous form is recommended for use in systemically unwell patients, the oral form being reserved for those who are stable or have improved following initial intravenous treatment. Voriconazole is widely distributed throughout tissues and in its oral form, is not usually associated with worsening of renal function. This is particularly important as it is often patients with comorbidities affecting renal function such as diabetes, who develop aspergillosis MOE and therefore require treatment with voriconazole.

\section{Conclusion}

In addition to aural swabs, biopsy of tissue from the external auditory canal is very important to obtain early confirmation of a fungal pathogen thereby allowing timely treatment to be commenced.

\section{References}

1. Grandis JR, Branstetter BF, Yu VL (2004) The changing face of malignant external otitis: clinical, radiological, and anatomic correlations. Lancet Infect Dis 4(1): 34-39.

2. Hamzany Y, Soudry E, Preis M (2011) Fungal malignant external otitis. J Infect 62: 226-231.

3. Carfrae MJ, Kesser BW (2008) Malignant otitis externa. Otolaryngol Clin North Am 41: 537-549.

4. C Halsey, H Lumley, J Luckit (2011) Necrotising external otitis caused by Aspergillus wentii: a case report. Mycoses 54: 211-213.

5. MJ Carfrae, BW Kesser (2008) Malignant otitis externa. Otolaryngologic Clinics of North America 41: 537- 549.

6. V Franco-Vidal, H Blanchet, C Bebear, H Dutronc, V Darrouzet (2007) Necrotizing external otitis: a report of 46 cases. Otology and Neurotology 28: 771-773.

7. Barrow HN, Levenson MJ (1992) Necrotizing malignant external otitis caused by Staphylococcus epidermidis. Arch Otolaryngol Head Neck Surg 118: 94-96.

8. Martínez-Berriotxoa A, Montejo M, Aguirrebengoa K (1997) Otomastoiditis caused by Aspergillus in AIDS. Enferm Infecc Microbiol Clin 15: 200-202.

9. TJ Walsh, EJ Anaissie, DW Denning (2008) Treatment of aspergillosis: clinical practice guidelines of the infectious diseases society of America. Clinical Infectious Diseases 46: 327-360. 
This work is licensed under Creative Commons Attribution 4.0 License DOI: $10.19080 /$ GJO.2017.07.555725
Your next submission with Juniper Publishers will reach you the below assets

- Quality Editorial service

- Swift Peer Review

- Reprints availability

- E-prints Service

- Manuscript Podcast for convenient understanding

- Global attainment for your research

- Manuscript accessibility in different formats

( Pdf, E-pub, Full Text, Audio)

- Unceasing customer service

Track the below URL for one-step submission https://juniperpublishers.com/online-submission.php 